Article

\title{
Vepris macrophylla Essential Oil Produces Notable Antiproliferative Activity and Morphological Alterations in Human Breast Adenocarcinoma Cells
}

\author{
Marisa Colone $^{1}$ (D) Filippo Maggi ${ }^{2}\left(\mathbb{D}\right.$, Rianasoambolanoro Rakotosaona ${ }^{3,4}$ (D) and Annarita Stringaro ${ }^{1, *(D)}$ \\ 1 National Center for Drug Research and Evaluation, Italian National Institute of Health, \\ Viale Regina Elena 299, 00161 Rome, Italy; marisa.colone@iss.it \\ 2 School of Pharmacy, University of Camerino, Via Sant'Agostino 1, 62032 Camerino, Italy; \\ filippo.maggi@unicam.it \\ 3 Centre National d'Application de Recherches Pharmaceutiques, Ambodivoanjo Ambohijatovo, \\ Rue RP Rahajarizafy Analamahitsy, BP 702, Antananarivo 101, Madagascar; rravalison@gmail.com \\ 4 Ecole Supérieure Polytechnique d'Antananarivo, University of Antananarivo, BP 1500, \\ Antananarivo 101, Madagascar \\ * Correspondence: annarita.stringaro@iss.it
}

check for updates

Citation: Colone, M.; Maggi, F.; Rakotosaona, R.; Stringaro, A. Vepris macrophylla Essential Oil Produces Notable Antiproliferative Activity and Morphological Alterations in Human Breast Adenocarcinoma Cells. Appl. Sci. 2021, 11, 4369. https:// doi.org/10.3390/app11104369

Academic Editor: Hari

Prasad Devkota

Received: 2 April 2021

Accepted: 7 May 2021

Published: 12 May 2021

Publisher's Note: MDPI stays neutral with regard to jurisdictional claims in published maps and institutional affiliations.

Copyright: (c) 2021 by the authors. Licensee MDPI, Basel, Switzerland. This article is an open access article distributed under the terms and conditions of the Creative Commons Attribution (CC BY) license (https:// creativecommons.org/licenses/by/ $4.0 /)$.

\begin{abstract}
Medicinal plants contain numerous bioactive molecules that synergistically provide therapeutic benefits. We have devoted our attention to various EOs without toxicity to normal cells, studying their activities against human cancer cells. In particular, we have studied the cytotoxicity of Vepris macrophylla (Baker) I. Verd. EO. V. macrophylla is an evergreen tree of Madagascar where is much appreciated as a source of traditional remedies. Its major volatile components are citral, i.e., a mixture of neral and geranial, citronellol and myrcene. The antiproliferative activities of V. macrophylla EO were studied against human breast adenocarcinoma cell line SKBR3. Cellular metabolism was analyzed by MTT assay at different concentrations of EO and at different times of incubation (24, 48 and $72 \mathrm{~h}$ ). Moreover, morphological and ultrastructural analyses were performed to study its antiproliferative effects against human adenocarcinoma cells, demonstrating the ability of $V$. macrophylla $\mathrm{EO}$, stored inside numerous intracellular vesicles, to damage both plasma membranes and disorganize the cytoskeleton protein as actin filaments.
\end{abstract}

Keywords: Vepris macropylla; essential oil; citral; antiproliferative activity; fluorescence and scanning electron microscopy; human breast cancer cell line

\section{Introduction}

Breast cancer is a major public health problem, representing the highest incidence rate of death for women [1,2]. The interest in products of natural origin from plants with different pharmacological activities that can be used in chemotherapy is increasingly broad. Many natural compounds have shown anticancer activities [3]. The most famous antineoplastic drug, paclitaxel, used for the treatment of breast cancer, was isolated from the bark of Taxus brevifolia Nutt. [4]. Furthermore, among the natural products, there are aloe-emodin, which is isolated from the root of Rheum palmatum L. and the leaves of aloe vera. Numerous in vitro studies have demonstrated that aloe-emodin is able to reduce the viability and proliferation of different human cancer cell lines, inducing apoptotic cell death and inhibiting adhesion and the migration process [5,6]. Another compound is curcumin, the active ingredient of turmeric, which is a polyphenolic compound with a broad range of medicinal properties, such as antibreast-cancer activity. Curcumin is able to enhance the effects of chemotherapeutic agents such as paclitaxel [3]. A natural stilbene and nonflavonoid polyphenol, resveratrol is present in grapes, peanuts and red wine. This natural product possesses anti-inflammatory, antioxidant, cardioprotective and anticancer properties [7]. Moreover, a synergistic effect has been reported by the combination of genistein 
and doxorubicin [8]. Additionally, rosemary (Rosmarinus officinalis L.) extract can increase the activity of the anti-breast-cancer agents tamoxifen, trastuzumab, and paclitaxel [9]. Currently, one of the most interesting approaches in the fight against this tumor comprises new therapeutic strategies using natural products in combination with synthetic drugs in order to increase the therapeutic index of the drug and reduce the many undesirable side effects caused by the doses used in typical chemotherapy protocols. After chemotherapy or radiotherapy, a number of adverse effects in patients occur [10]. A natural flavonoid, quercetin has anti-inflammatory and antioxidative effects. After high dose chemotherapy, quercetin, administered in capsules of $250 \mathrm{mg}$ (twice daily for four weeks), can reduce oral mucositis events in patients with blood malignancy [11]. A combination of curcumin and $\alpha$-tocopherol regulates rat liver enzymes via inhibition of oxidative stress, revealing protection against cisplatin-induced hepatotoxicity [12]. Naringenin, a natural flavanone isolated from Thymus vulgaris L., has growth inhibitory and chemosensitization effects on human breast and colorectal cancer [13]. Naringenin can reduce the nephrotoxicity induced by daunorubicin treatment in rats [14]. Several drugs derived from natural products have already received clinical approval, and many are currently undergoing in clinical trials. To date, the Food and Drug Administration (FDA) has approved the administration of resveratrol and quercetin [15].

Essential oils (EOs) are products obtained from vegetable raw material [16]. They are complex, multicomponent systems composed of volatile small molecular weight components, mainly terpenes and non-terpene components. EOs have been used for a long time by various traditional medicine systems as antiseptic agents [17]. Nowadays, scientific evidence is available showing that certain EOs have antimicrobial, antimycotic, antiviral, antioxidant, immunomodulant and anticancer properties [18,19]. Some of these characteristics are related to their functions in plants. Vepris macrophylla (Baker) I. Verd. (Rutaceae) is a tree endemic to Madagascar, where it is known by many names, such as itampody, ampodiberavina, mampodifotsy, mampody (evoking its euphoric properties) (Figure 1) [20]. Indeed, the roots of V. macrophylla are traditionally used to manufacture euphoric alcoholic beverages. In Malagasy ethnomedicine, each part of the plant has a specific use. The root bark, grated and macerated in water, is administered as a drink to treat nervous depression or apathetic states. Fruits are used to prepare steam baths during convalescence periods following infectious diseases. The leaves are used to regulate the coronary blood flow. [21-25]. The EO obtained from V. macrophylla leaves showed antimicrobial activities for the treatment of infectious diseases [26]. Furthermore, it was effective against phytopathogenic fungi such as Phytophthora cryptogea and Fusarium avenaceum [27].

In our previous study, the V. macrophylla EO showed notable effects on human tumor cells, notably breast adenocarcinoma and colon carcinoma cell lines, highlighting its cytotoxicity [26]. These results pushed us to further explore the effects of this EO on tumor cells. Thus, in the present study, we evaluated the antiproliferative activity of $V$. macrophylla EO, at different times and concentrations, on human breast cell line SKBR3.

Furthermore, the ultrastructural morphological alterations of SKBR3 cells were evaluated by fluorescence and scanning electron microscopy analyses. 


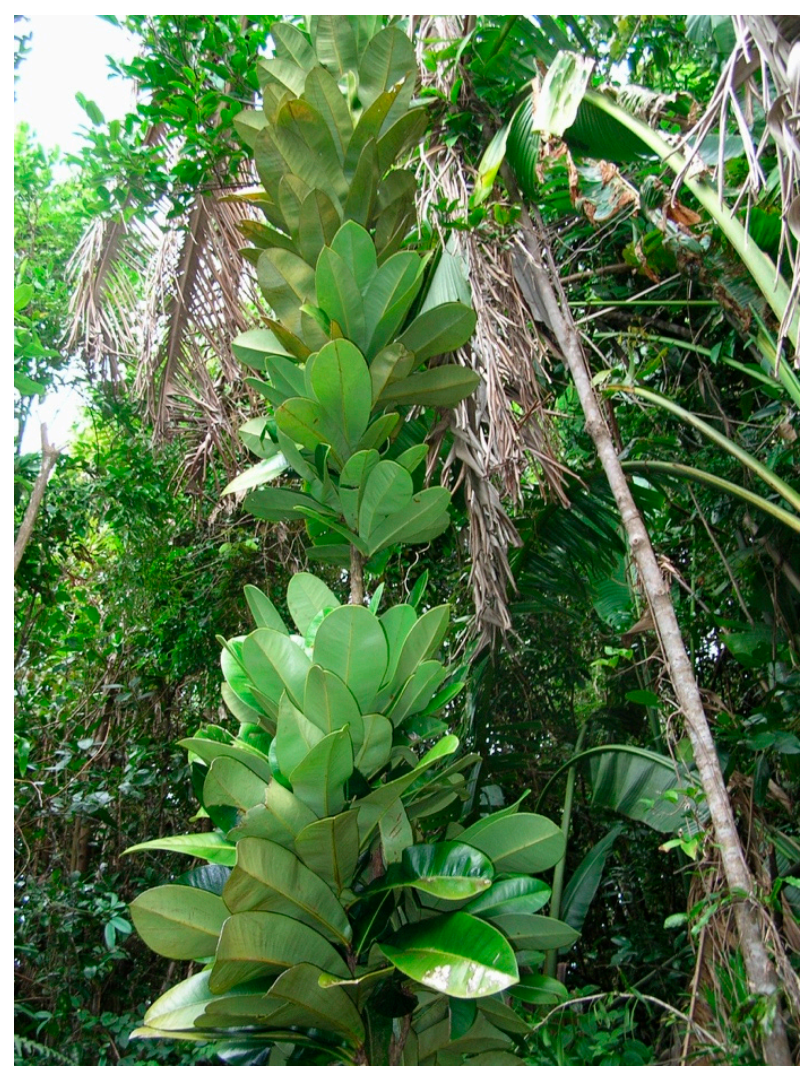

Figure 1. Vepris macrophylla tree.

\section{Materials and Methods}

\subsection{Plant Material and Essential Oil (EO) Extraction and Composition}

The EO was obtained by hydrodistillation of V. macrophylla leaves, collected in the east coast of Madagascar (Sahamamy/Analalava), using a portable alembic as reported in Maggi et al. [26]. Following GC and GC-MS analysis the following major components were detected in the EO chemical profile: geranial (33.2\%), neral (23.1\%), citronellol (14.5\%), and myrcene $(8.3 \%)$.

\subsection{Cell Culture}

SKBR3 cell line from human breast cancer was obtained from American Type Culture Collection (ATCC, Rockville, MD, USA) and was grown in Dulbecco's Modified Eagle's Medium (DMEM) medium with $10 \%$ fetal bovine serum (HyClone ${ }^{\mathrm{TM}} \mathrm{FBS}$ (U.S.A. origin), Characterized), $1 \%$ nonessential amino acids, $1 \%$ L-glutamine, $100 \mathrm{IU}$ per $\mathrm{mL}$ penicillin, $100 \mathrm{IU}$ per $\mathrm{mL}$ streptomycin, in a humidified atmosphere at $37^{\circ} \mathrm{C}$ with $5 \% \mathrm{CO}_{2}$.

\subsection{Cell Viability Assay}

MTT assay was utilized to evaluate cell viability. Briefly, cells were seeded for $24 \mathrm{~h}$ in a 96-well plate (NunclNunclonTM, NuncGmbH \& Co., Wiesbaden, Germany) with a density of $1.2 \times 10^{4}$ cells/well. Then were treated with $V$. macrophylla EO at concentration of $1.25 ; 2.5 ; 5$ and $10 \mu \mathrm{g} / \mathrm{mL}$ for 24,48 and $72 \mathrm{~h}$. After the incubation period, $0.5 \mathrm{mg} / \mathrm{mL}$ of MTT (Sigma, Deisenhofen, Germany) was added to each well for $2 \mathrm{~h}$ at $37^{\circ} \mathrm{C}$ and the cells were dissolved with $200 \mu \mathrm{L} /$ well of dimethylsulfoxide (Merck, Darmstadt, Germany). The absorbance of formazan was read at $570 \mathrm{~nm}$ on a scanning microtiter spectrophotometer plate reader. The results were calculated as the percentage of viability in relation to the untreated cells standardized to $100 \%$. They are the mean \pm SD of three separate experiments done in triplicate. 


\subsection{Immunfluorescence Microscopy}

SKBR3 cells were grown for $24 \mathrm{~h}$ on $12 \mathrm{~mm}$ diameter coverslips and treated with $V$. macrophylla EO for an incubation time of 24 and $48 \mathrm{~h}$. Cells were then fixed with $4 \%$ paraformaldehyde for $30 \mathrm{~min}$ and were permeabilized with 0.5\% Triton X-100 (Sigma Chemicals Co., St. Louis, MO, USA) for $5 \mathrm{~min}$. For actin detection, cells were stained with FITC-phalloidin (Sigma) at room temperature for $30 \mathrm{~min}$. For nuclei detection, cells were stained with Hoechst 33258 (Sigma-Aldrich, St. Louis, MO, USA; \#861405) at $37^{\circ} \mathrm{C}$ for $15 \mathrm{~min}$. After the washing with PBS coverslips were mounted with glycerol-phosphate and images were acquired with a Nikon Microphot fluorescence microscope (Nikon Instruments, Melville, NY, USA) equipped with a Zeiss CCD camera (Carl Zeiss, Oberkochen, Germany).

\subsection{Scanning Electron Microscopy (SEM)}

SEM analysis allowed the study of cell surface modifications induced by $V$. macrophylla EO. Samples were grown for $24 \mathrm{~h}$ on glass coverslips and treated for 24,48 and $72 \mathrm{~h}$ with $V$. macrophylla EO with a concentration of $0.01 ; 0.1 ; 1.25$ and $2.5 \mu \mathrm{g} / \mathrm{mL}$. Then cells were fixed in $2.5 \%$ glutaraldehyde in $0.2 \mathrm{M} \mathrm{Na}$-cacodylate buffer for $2 \mathrm{~h}$ and postfixed with $1 \%(w / w)$ $\mathrm{OsO}_{4}$ for $1 \mathrm{~h}$. Subsequently, cells were dehydrated using an ethanol gradient. After the passage in $100 \%$ ethanol, the samples were submitted to drying with $\mathrm{CO}_{2}$ (Critical point dryer CPD 030, Bal-Tec AG, Lichtenstein) and gold coated by sputtering (SCD 050 Blazers device, Bal-Tec). Samples were observed with a scanning electron microscope FE-SEM Quanta Inspect F (FEI-Thermo Fisher Scientific; Eindhoven-The Netherlands).

\subsection{Statistical Analysis}

All data were repeated in at least three different experiments, and results are expressed as the mean \pm standard deviation. Statistical differences were determined using a one-way ANOVA test and values with $p<0.05$ being considered significant.

\section{Results}

\subsection{Evaluation of Citotoxicity of V. macrophylla EO}

MTT assay was used to study cell viability and consequently the proliferative capacity of SKBR3 adenocarcinoma cells after treatment with $V$. macrophylla EO. This assay allows to evaluate the toxicity of a substance, through the comparison of cell viability indices obtained from treated cells compared to control. Figure 2 shows the results of the MTT assay obtained from treatments at 24,48 and $72 \mathrm{~h}$ at different concentrations of $V$. macrophylla EO $(1.25 ; 2.5 ; 5$ and $10 \mu \mathrm{g} / \mathrm{mL})$ on human breast adenocarcinoma cells SKBR3.

The results showed that $V$. macrophylla $\mathrm{EO}$ was able to reduce cell proliferation below $60 \%$, even at the lowest concentrations $(1.25 \mu \mathrm{g} / \mathrm{mL})$ after $24 \mathrm{~h}$ of treatment. This trend was also observed at longer times (48 and $72 \mathrm{~h})$ for all other concentrations $(2.5 ; 5$, and $10 \mu \mathrm{g} / \mathrm{mL})$.

\subsection{Immunoflorescence Microscopy Observations}

In the course of experimental analyses, we performed investigations by fluorescence microscopy that allowed us to evaluate the morphological alterations of cells after treatment with $V$. macrophylla EO at different times and concentrations.

After treatment with $V$. macrophylla EO, the SKBR3 cells were labeled both with Hoechst 33258, which is used to highlight morphological-ultrastructural alterations in the nucleus, and with FITC-phalloidin, to highlight changes in the cell cytoskeleton and actin filaments, induced by different treatments with EO (Figure 3). The micrographs obtained by fluorescence microscopy showed that at 1.25 and $2.5 \mu \mathrm{g} / \mathrm{mL}$ concentrations, the lowest concentrations of EO, after $24 \mathrm{~h}$ of treatment, the nuclei still possessed a morphology similar to those of the control cells, while the actin filaments of the cytoskeleton revealed a significant rearrangement of their ultrastructures. Moreover, in some cells, there were numerous vesicular structures, probably containing the same EO (Figure 4a,b, see arrow- 
heads). Images of cells treated with the same concentration of EO for an incubation time of $48 \mathrm{~h}$ revealed a reduction of nuclei diameters of the cells. Moreover, the morphologies of the actin filament appeared altered, and numerous green fluorescence points were identified exclusively around the nucleus (Figure $4 \mathrm{c}, \mathrm{d}$ ). This result reveals that $V$. macrophylla EO is able to disorganize the actin filament network (see also Figure 3).

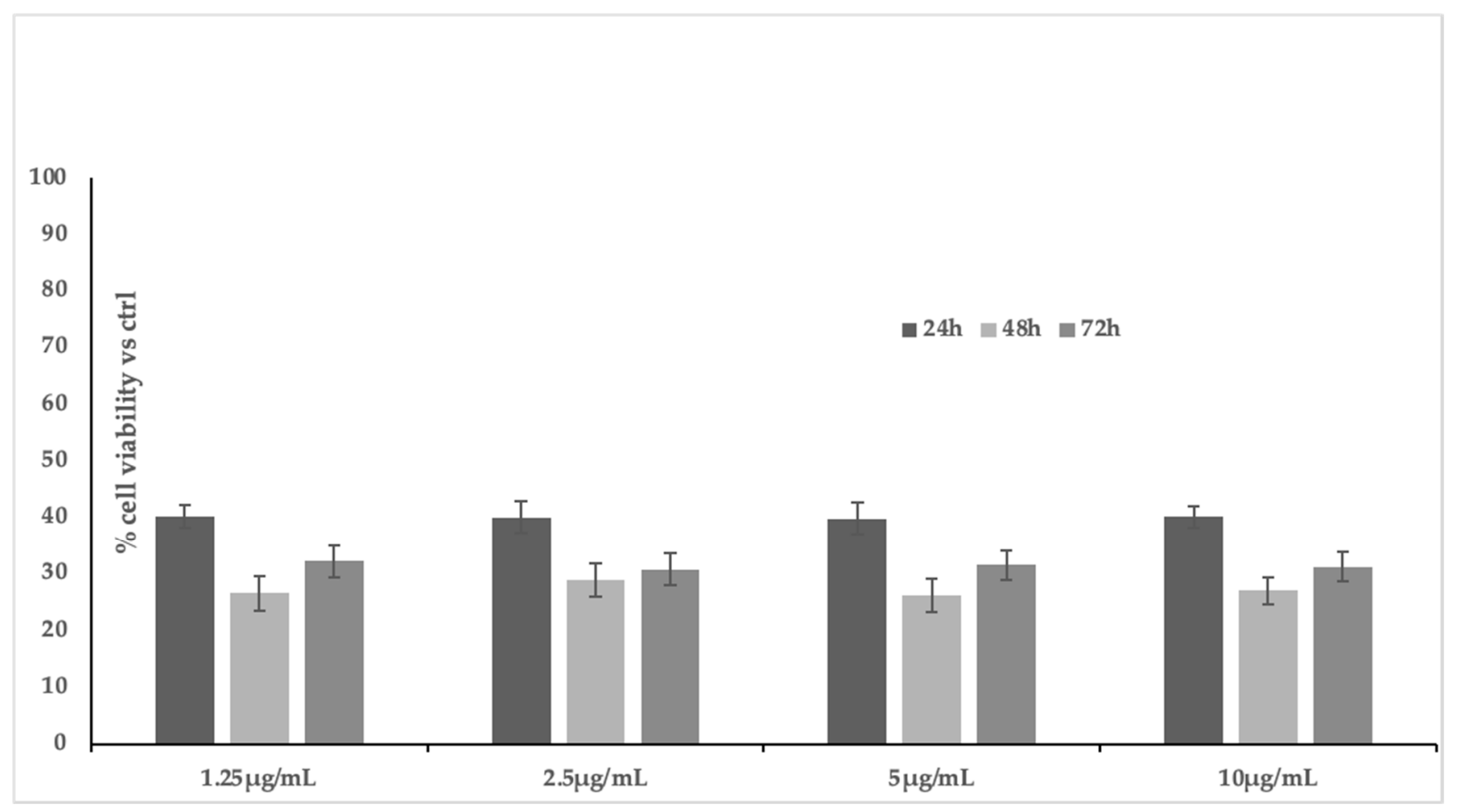

Figure 2. Evaluation of SKBR3 cell viability treated for 24, 48 and $72 \mathrm{~h}$ with different concentrations of EO obtained from Vepris macrophylla leaves. Cell viability was calculated considering the control value and standardized to $100 \%$. Data represent mean ds $(n=3)$.

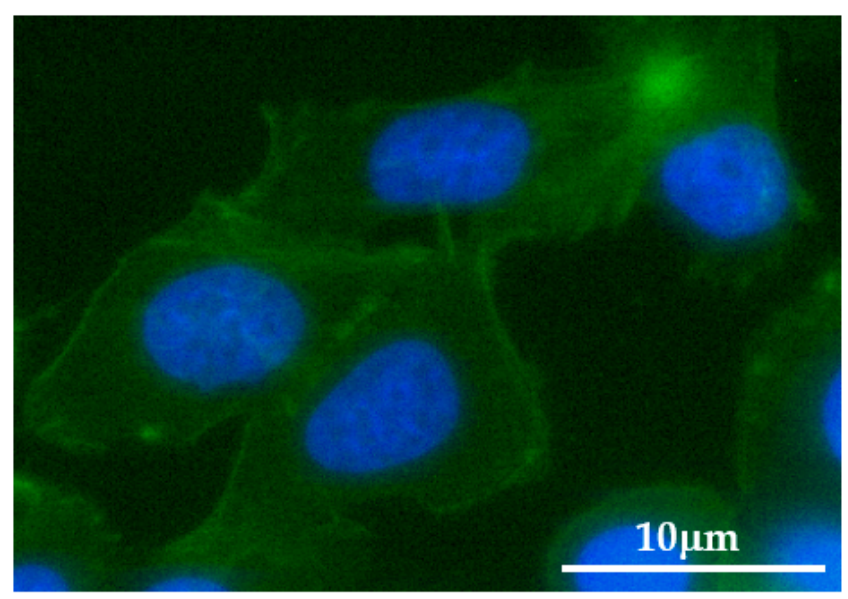

Figure 3. Images after double-cell staining with FITC-phalloidin (green) and Hoechst 33258 (blue) in SKBR3 control cells. 

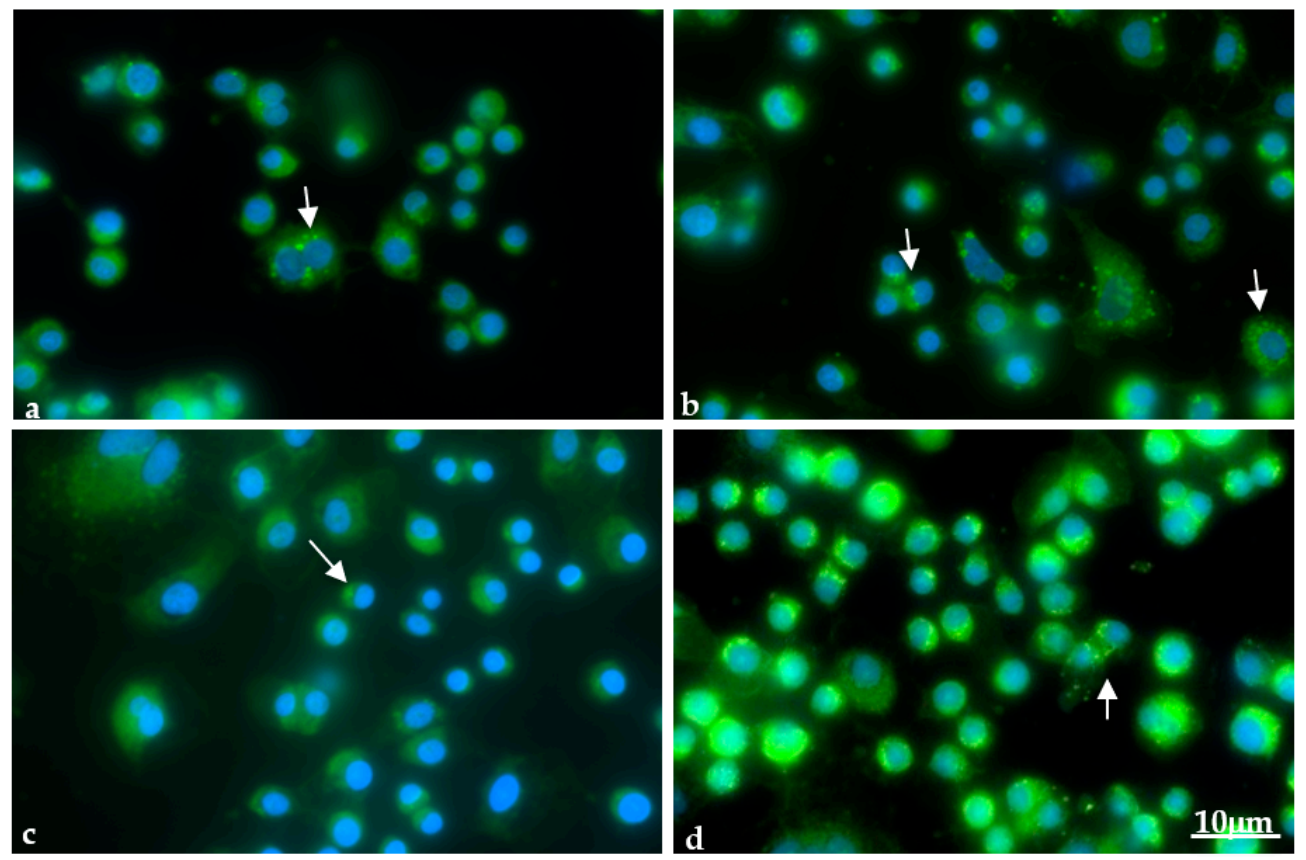

Figure 4. Immunofluorescence micrographs shown the morphological alterations on SKBR3 cells induced by Vepris macrophylla EO after treatment with $1.25(\mathbf{a}, \mathbf{c})$ and $2.5 \mu \mathrm{g} / \mathrm{mL}(\mathbf{b}, \mathbf{d})$ concentrations at two incubation times $24 \mathrm{~h}(\mathbf{a}, \mathbf{b})$ and $48 \mathrm{~h}(\mathbf{c}, \mathbf{d})$. Arrowheads indicate probably vesicles filled with EO.

Immunofluorescence observations of SKBR3 cells treated with 5 and $10 \mu \mathrm{g} / \mathrm{mL}$, at $48 \mathrm{~h}$, were in agreement with results obtained by MTT assay (see Figure 2), showing both the same morphological alterations and numerous vesicles inside the cytoplasm of cancer cells (Figure 5a,b, arrowheads).
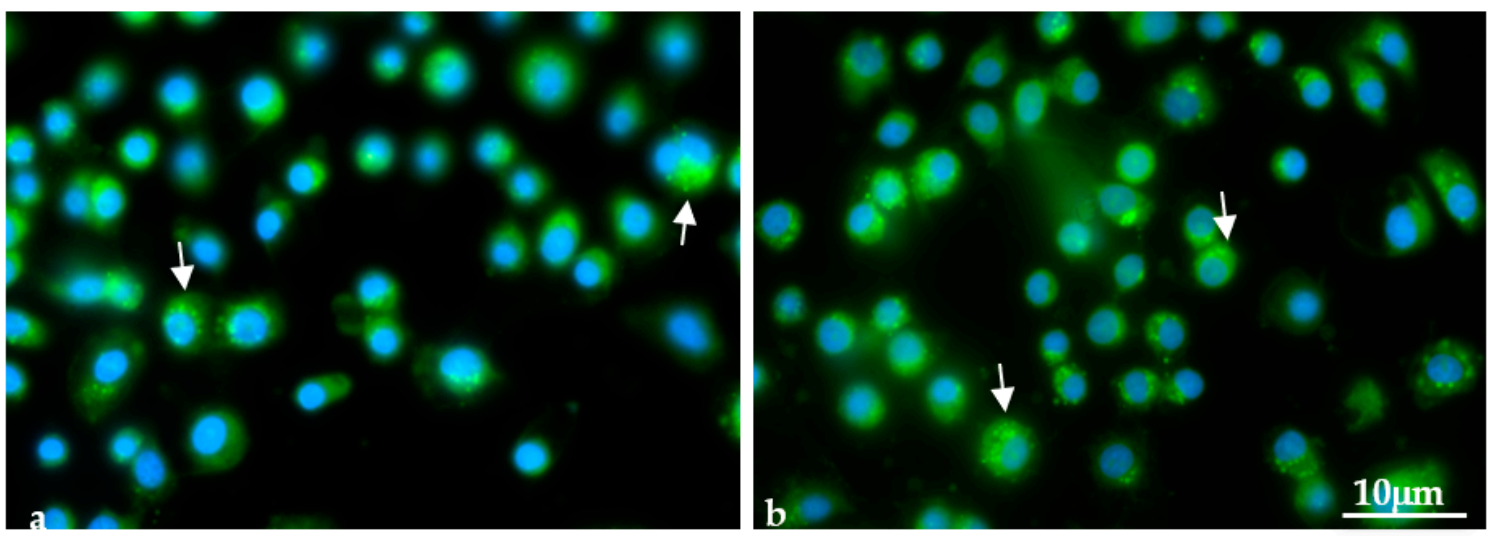

Figure 5. Morphological alterations of SKBR3 cells after treatment with $5(\mathbf{a})$ and $10(\mathbf{b}) \mu \mathrm{g} / \mathrm{mL}$ of Vepris macrophylla EO at $48 \mathrm{~h}$. Arrowheads indicate probably vesicles filled with EO.

\subsection{SEM Analysis}

SEM observations of SKBR3 control cells at 24,48 and $72 \mathrm{~h}$ showed numerous microvilli and random "ruffles" on the cell surface (Figure 6). 

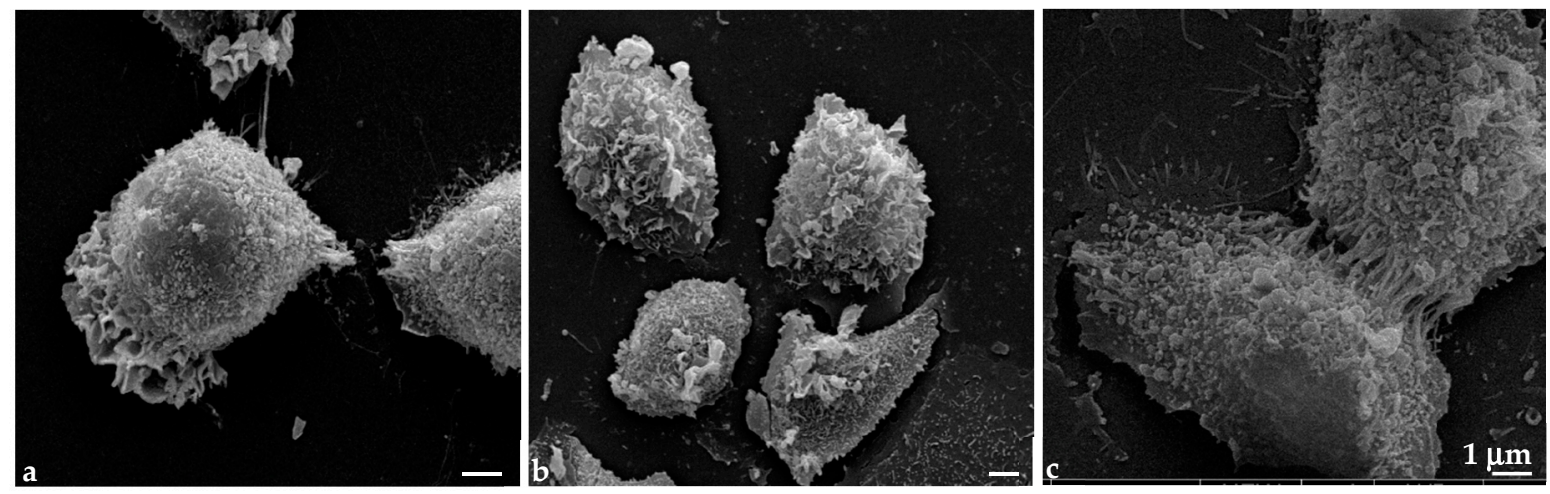

Figure 6. SEM images of SKBR3 control cells at 24, 48 and $72 \mathrm{~h}$ (a-c respectively).

After treatment with EO at different concentrations, cancer cells appeared very damaged. Figures 7-9 show important ultrastructural alterations of SKBR3 cells. The morphological alterations are clearly visible after only $24 \mathrm{~h}$ of treatment (Figure 7) with four different concentrations of EO $(0.01 ; 0.1 ; 1.25$ and $2.5 \mu \mathrm{g} / \mathrm{mL}$, respectively). Moreover, at higher concentrations (1.25 and $2.5 \mu \mathrm{g} / \mathrm{mL})$, SKBR3 cells appeared flat and adherent to the substrate, probably due the effect on cytoskeletal actin disorganization, as also shown by fluorescence microscopy analysis (Figure 4 ). When cells were treated with the lowest concentrations of EO $(0.01$ and $0.1 \mu \mathrm{g} / \mathrm{mL})$, at $48 \mathrm{~h}$, the plasma membranes were entirely destroyed (Figure 8a,b). Cells showed plasma membrane alterations like those observed $24 \mathrm{~h}$ after treatment with the highest concentration $(2.5 \mu \mathrm{g} / \mathrm{mL})$ of EO. Figure $8 \mathrm{~d}$ shows cells treated with $2.5 \mu \mathrm{g} / \mathrm{mL}$ for $48 \mathrm{~h}$, in which the plasma membranes are completely damaged. Finally, as a dose-dependent effect, after $72 \mathrm{~h}$, these morphological alterations were clearly visible in all SKBR3 cells treated with $V$. macrophylla EO (Figure 9a-c).
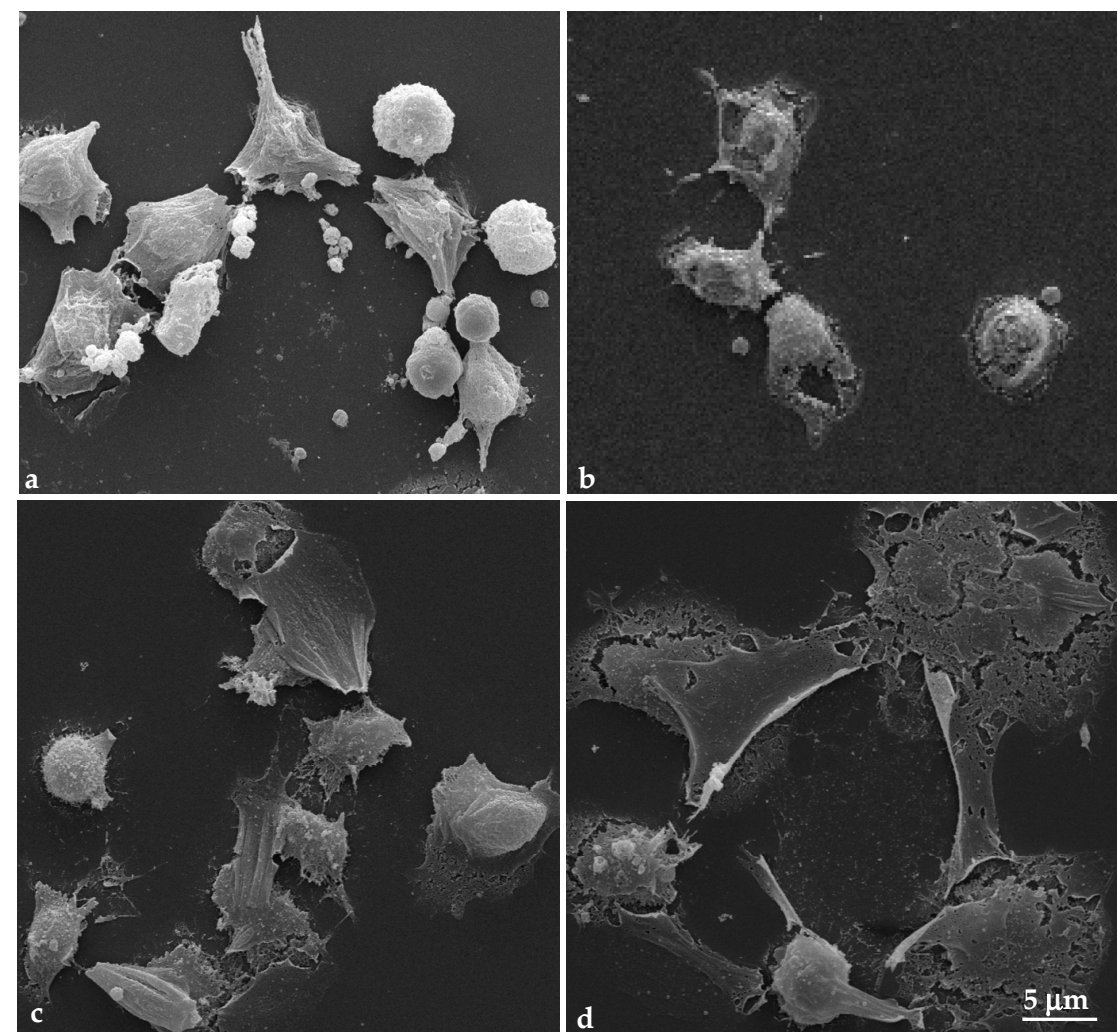

Figure 7. SEM micrographs of SKBR3 cells after $24 \mathrm{~h}$ of V. macrophylla EO incubation (0.01 (a), 0.1 (b), 1.25 (c) and $2.5(\mathbf{d}) \mu \mathrm{g} / \mathrm{mL}$, respectively). 


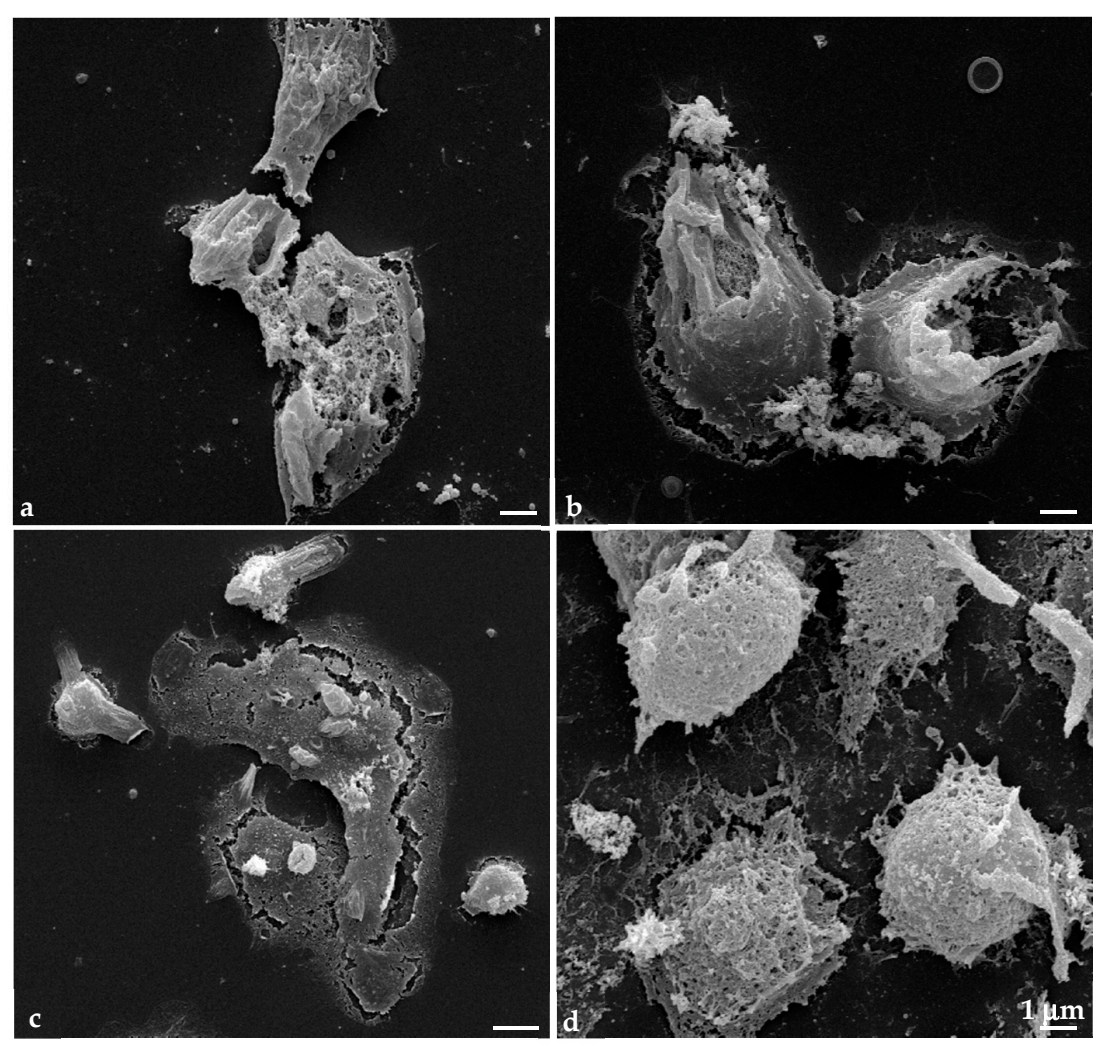

Figure 8. SEM micrographs of SKBR3 cells after $48 \mathrm{~h}$ of $V$. macrophylla EO incubation (0.01 (a), 0.1 (b), 1.25 (c) and $2.5(\mathbf{d}) \mu \mathrm{g} / \mathrm{mL}$, respectively).

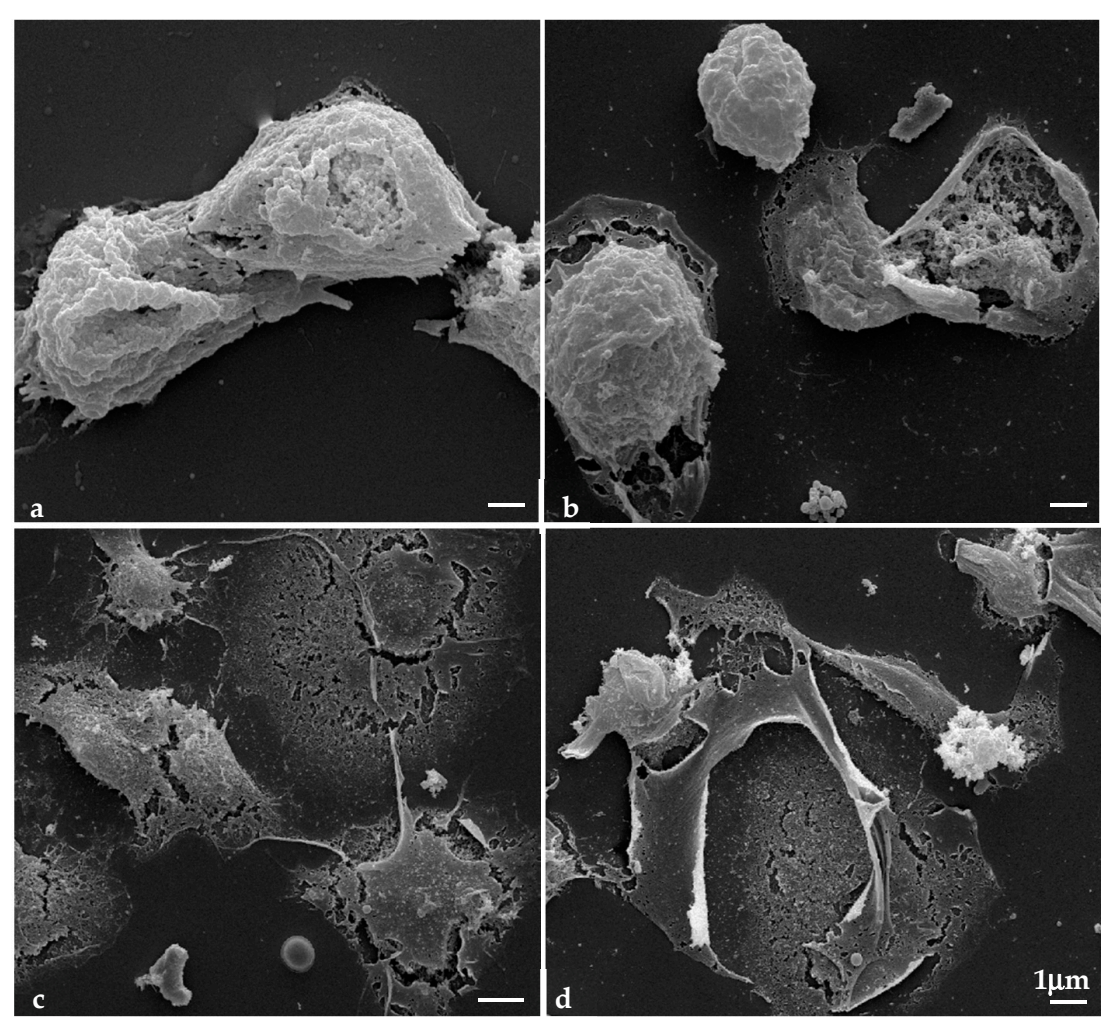

Figure 9. Micrographs of SKBR3 cells after $72 \mathrm{~h}$ of $V$. macrophylla EO incubation (0.01 (a), 0.1 (b), 1.25 (c) and $2.5(\mathbf{d}) \mu \mathrm{g} / \mathrm{mL}$, respectively). 
Figure 10 shows immunofluorescence and SEM images of the SKBR3 cells with some vesicles on and inside the cytoplasm (arrowheads). These structures, containing the stored EO of V. macrophylla, could slow the release of EOs, enhancing both the antiproliferative activity and alteration of cancer cell adhesion on the substrates by actin filaments.
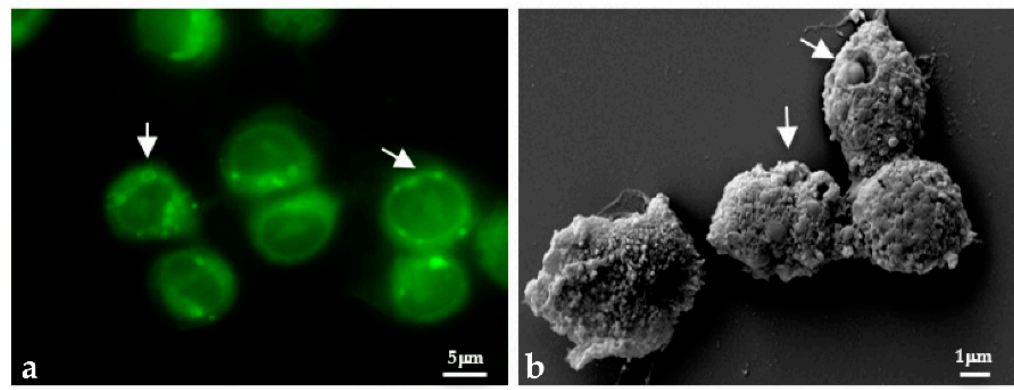

Figure 10. SKBR3 treated with Vepris macrophylla EO at $24 \mathrm{~h}$ with $1.25 \mu \mathrm{g} / \mathrm{mL}$ (a) fluorescence microscopy and (b) scanning electron microscopy micrographs. Arrowheads indicate probably vesicles filled with EO.

\section{Discussion}

EOs and some of their components exert antitumor activities against numerous cancer models, such as colon [28], lung and liver [29], by affecting multiple pathways [30-33]. Di Martile et al. [34] summarized studies showing the properties of EOs to induce in vitro and in vivo cell death in melanoma models. They also indicated the use of EOs in clinical trials with the reduction of the side effects in cancer patients. Moreover, frankincense, pine needle and geranium EOs are also able to suppress tumor progression through the regulation of the AMPK/mTOR pathway in breast cancer [35]. Several EOs also have chemopreventive properties [34]. In eukaryotic cells, EOs can cause depolarization of mitochondrial membranes and decrease their fluidity. In this way, EOs are able to induce severe damage in the mitochondria, leading to cell death. Bhakkiyalakshmi et al. demonstrated that carvacrol, a phenolic monoterpenoid, is able to cause cell death as apoptosis. This process is associated with the production of free radicals that cause the rapid consumption of the intracellular pool of antioxidants [36]. Another study by Arunasree et al. evaluated the mechanism of action of carvacrol in the MDA-MB-231 cell line. This monoterpenoid induced cell death via cytochrome $C$ release after mitochondria permeabilization [37]. Moreover, we also demonstrated the antitumoral activity of Tea Tree Oil (TTO), with an apoptotic effect on melanoma cell lines [38]. In general, the cytotoxic effects of EOs in toto, or those of some of their components, such as monoterpenoids [39], are due to their lipophilicity, which allows them to cross membranes and destroy them [40,41].

Herein, the damage caused by V. macrophylla EO to the cell membranes of SKBR3 cells can be attributed to its main component, citral, which is a mixture of the two monoterpenes, neral and geranial. Citral is generally recognized as safe (GRAS) by the FDA, and is commonly used as a flavoring agent in the EU. On the other hand, this compound is endowed with antimicrotubule [42] and chemopreventive properties [43]. Several studies have shown that citral is able to cause cell death to tumor cells and severely damage cytoskeletal structures. On the other hand, other components occurring in the V. macrophylla $\mathrm{EO}$, including both major and minor constituents, may be involved in the overall synergistic effect normally displayed by the EO [26]. Moreover, as demonstrated by other authors [44], our results show that $V$. macrophylla $\mathrm{EO}$ significantly changes the cytoskeletal organization of SKBR3 cancer cells, suppressing actin cytoskeletal rearrangement and destroying the cell membrane thanks in part to its monoterpenoid activities. Furthermore, this EO significantly decreased the proliferation and migration of human SKBR3 cells in a concentration and time-dependent manner. 


\section{Conclusions}

In the present study, we examined the in vitro antitumoral activities of $V$. macrophylla EO on the SKBR3 human adenocarcinoma cell line. The results demonstrated that this EO is able to induce numerous ultrastructural alterations thanks its ability to both disorganize the cytoskeleton and damage the plasma membrane. Thus, these results suggest a potential use of V. macrophylla $\mathrm{EO}$ and its main components as a chemosensitizer in clinical practice. Future studies should clarify the mechanism of action and biochemical process activated by this EO. Other studies will be performed using fluorescence microscopy to study all cytoskeletal proteins in order to assess whether these complexes will be used to reduce the degree of invasiveness of human cancer cells by increasing their ability to adhere to the substrate.

Author Contributions: Conceptualization: F.M. and A.S.; Figures preparation: M.C. and A.S.; Writing - original draft preparation: F.M., M.C. and A.S.; Analysis of essential oils composition: R.R. and F.M.; Data analysis: F.M., M.C. and A.S. All authors have read and agreed to the published version of the manuscript.

Funding: This research was partially funded by Istituto Superiore di Sanità, ISS (Ministry of HealthISS funding) and by University of Camerino.

Informed Consent Statement: This study did not involve human.

Data Availability Statement: All the data are available.

Acknowledgments: We thank Stefania Muran for experimental support in ISS laboratory.

Conflicts of Interest: No conflict of interest are present Fondo di Ateneo per la Ricerca (FAR 2014/2015) in this study.

\section{References}

1. Ferlay, J.; Héry, C.; Autier, P.; Sankaranarayanan, R. Global Burden of Breast Cancer. In Breast Cancer Epidemiology; Li, C., Ed.; Springer: New York, NY, USA, 2010; pp. 1-19. [CrossRef]

2. Liu, L.; Kawashima, M.; Toi, M. Breast cancer in global health: Beyond diversity and inequality. Int. J. Surg. Global Health 2020, 3, e32. [CrossRef]

3. Samistha, M.; Rajn, D. Natural products for the management and prevention of breast cancer. Evid. Based Complement. Alternat. Med. 2018. [CrossRef]

4. Amaral, R.G.; Albuquerque dos Santos, S.; Nalone Andrade, L.; Severino, P.; Andrade Carvalho, A. Natural Products as Treatment against Cancer: A Historical and Current vision. Clin. Oncol. 2019, 4, 1562.

5. Chen, R.; Zhang, J.; Hu, Y.; Wang, S.; Chen, M.; Wang, Y. Potential antineoplastic effects of Aloe-emodin: A comprehensive review. Am. J Chin. Med. 2014, 42, 275-288. [CrossRef] [PubMed]

6. Dong, X.; Zeng, Y.; Liu, Y.; You, L.; Yin, X.; Fu, J.; Ni, J. Aloe-emodin: A review of its pharmacology, toxicity, and pharmacokinetics. Phytother. Res. 2020, 34, 270-281. [CrossRef] [PubMed]

7. Ko, J.H.; Sethi, G.; Um, J.Y.; Shanmugam, M.K.; Arfuso, F.; Kumar, A.P.; Bishayee, A.; Ahn, K.S. The Role of Resveratrol in Cancer Therapy. Int. J. Mol. Sci. 2017, 18, 2589. [CrossRef]

8. Xue, J.P.; Wang, G.; Zhao, Z.B.; Wang, Q.; Shi, Y. Synergistic cytotoxic effect of genistein and doxorubicin on drug-resistant human breast cancer MCF-7/Adr cells. Oncol. Rep. 2014, 32, 1647-1653. [CrossRef]

9. González-Vallinas, M.; Molina, S.; Vicente, G.; Sánchez-Martínez, R.; Vargas, T.; García-Risco, M.R.; Fornari, T.; Reglero, G.; Ramírez de Molina, A. Modulation of estrogen and epidermal growth factor receptors by rosemary extract in breast cancer cells. Electrophoresis 2014, 35, 1719-1727. [CrossRef]

10. Zhang, Q.Y.; Wang, F.X.; Jia, K.K.; Kong, L.D. Natural Product Interventions for Chemotherapy and Radiotherapy-Induced Side Effects. Front. Pharmacol. 2018, 9, 1253. [CrossRef]

11. Kooshyar, M.M.; Mozafari, P.M.; Amirchaghmaghi, M.; Pakfetrat, A.; Karoos, P.; Mohasel, M.R.; Orafai, H.; Azarian, A.A. A Randomized Placebo- Controlled Double Blind Clinical Trial of Quercetin in the Prevention and Treatment of ChemotherapyInduced Oral Mucositis. J. Clin. Diagn. Res. 2017, 11, ZC46-ZC50. [CrossRef]

12. Palipoch, S.; Punsawad, C.; Koomhin, P.; Suwannalert, P. Hepatoprotective effect of curcumin and alpha-tocopherol against cisplatin-induced oxidative stress. BMC Complement. Altern. Med. 2014, 14, 111. [CrossRef] [PubMed]

13. Abaza, M.S.; Orabi, K.Y.; Al-Quattan, E.; Al-Attiyah, R.J. Growth inhibitory and chemo-sensitization effects of naringenin, a natural flavanone purified from Thymus vulgaris, on human breast and colorectal cancer. Cancer Cell Int. 2015, 15, 46. [CrossRef] 
14. Karuppagounder, V.; Arumugam, S.; Thandavarayan, R.A.; Pitchaimani, V.; Sreedhar, R.; Afrin, R.; Harima, M.; Suzuki, H.; Suzuki, K.; Nakamura, M.; et al. Naringenin ameliorates daunorubicin induced nephrotoxicity by mitigating AT1R, ERK1/2-NFkB p65 mediated inflammation. Int. Immunopharmacol. 2015, 28, 154-159. [CrossRef] [PubMed]

15. Montané, X.; Kowalczyk, O.; Reig-Vano, B.; Bajek, A.; Roszkowski, K.; Tomczyk, R.; Pawliszak, W.; Giamberini, M.; MocekPłóciniak, A.; Tylkowski, B. Current Perspectives of the Applications of Polyphenols and Flavonoids in Cancer Therapy. Molecules 2020, 25, 3342. [CrossRef]

16. Celia, C.; Trapasso, E.; Locatelli, M.; Navarra, M.; Ventura, C.A.; Wolfram, J.; Carafa, M.; Morittu, V.M.; Britti, D.; Di Marzio, L.; et al. Anticancer activity of liposomal bergamot essential oil (BEO) on human neuroblastoma cells. Colloids Surf. B Biointerfaces. 2013, 112, 548-553. [CrossRef]

17. Ríos, J.L.; Recio, M.C. Medicinal plants and antimicrobial activity. J. Ethnopharmacol. 2005, 100, 80-84. [CrossRef]

18. Edris, A.E. Pharmaceutical and therapeutic potentials of essential oils and their individual volatile constituents: A review. Phytother. Res. 2007, 21, 308-323. [CrossRef]

19. Blowman, K.; Magalhães, M.; Lemos, M.F.L.; Cabral, C.; Pires, I.M. Anticancer Properties of Essential Oils and Other Natural Products. Evid. Based. Complement. Alternat. Med. 2018, 2018, 3149362. [CrossRef] [PubMed]

20. Novy, J.W. Medicinal plants of the eastern region of Madagascar. J. Ethnopharmacol. 1997, 55, 119-126. [CrossRef] [PubMed]

21. Garcia, G.; Charmillon, J.M.; Roux, E.; Sutour, S.; Rakotozafy, J.B.; Désiré, O.; Paoli, M.; Tomi, F.; Rabehaja, J.R. Chemical composition of leaf and bark essential oils of Vepris unifoliata from Madagascar. JEOR 2017, 3, 214-220.

22. Billet, D.; Favre-Bonvin, J. Constituants de l'huile essentielle de Vepris madagascarica Essential oil composition of Vepris madagascarica. Phytochemistry 1973, 2, 1194-1197. [CrossRef]

23. Rabehaja, D.J.R.; Ihandriharison, H.; Ramanoelina, P.A.R.; Ratsimamanga-Urveg, S.; Bighelli, A.; Casanova, J.; Tomi, F. Leaf oil from Vepris madagascarica (Rutaceae), source of (E)- anethole. Nat. Prod. Commun. 2013, 8, 1165-1166. [CrossRef] [PubMed]

24. Poitou, F. Chemical composition of Vepris elliotii essential oil. J. Essent. Oil Res. 1995, 7, 447-449. [CrossRef]

25. Boiteau, P.; Boiteau, M.; Allorge-Boiteau, L. Dictionnaire des Noms Malgaches des Ve'ge 'taux; Editions Alzieu: Grenoble, France, 1999.

26. Maggi, F.; Randriana, R.F.; Rasoanaivo, P.; Nicoletti, M.; Quassinti, L.; Bramucci, M.; Lupidi, G.; Petrelli, D.; Vitali, L.A.; Papa, F.; et al. Chemical composition and in vitro biological activities of the essential oil of Veprys macrophylla (Baker) I. Verd. Endemic to Madagascar. Chem. Biodivers. 2013, 10, 1-12. [CrossRef]

27. Giamperi, L.; Bucchini, A.E.A.; Ricci, D.; Tirillini, B.; Nicoletti, M.; Rakotosaona, R.; Maggi, F. Vepris macrophylla (Baker) I. Verd Essential Oil: An Antifungal Agent against Phytopathogenic Fungi. Int. J. Mol. Sci. 2020, 21, 2776. [CrossRef]

28. Polo, M.P.; Crespo, R.; de Bravo, M.G. Geraniol and simvastatin show a synergistic effect on a human hepatocarcinoma cell line. Cell Biochem. Funct. 2011, 29, 452-458. [CrossRef]

29. Slamenová, D.; Horváthová, E.; Sramková, M.; Marsálková, L. DNA-protective effects of two components of essential plant oils carvacrol and thymol on mammalian cells cultured in vitro. Neoplasma 2007, 54, 108-112.

30. Sitarek, P.; Rijo, P.; Garcia, C.; Skała, E.; Kalemba, D.; Białas, A.J.; Szemraj, J.; Pytel, D.; Toma, M.; Wysokińska, H.; et al. Antibacterial, Anti-Inflammatory, Antioxidant, and Antiproliferative Properties of Essential Oils from Hairy and Normal Roots of Leonurus sibiricus L. and Their Chemical Composition. Oxid. Med. Cell Longev. 2017, 2017, 7384061. [CrossRef]

31. Bhalla, Y.; Gupta, V.K.; Jaitak, V. Anticancer activity of essential oils: A review. J. Sci. Food Agric. 2013, 93, 3643-3653. [CrossRef] [PubMed]

32. Fitsiou, E.; Anestopoulos, I.; Chlichlia, K.; Galanis, A.; Kourkoutas, I.; Panayiotidis, M.I.; Pappa, A. Antioxidant and Antiproliferative Properties of the Essential Oils of Satureja thymbra and Satureja parnassica and their Major Constituents. Anticancer Res. 2016, 36, 5757-5763. [CrossRef]

33. Saleh, A.M.; Al-Qudah, M.A.; Nasr, A.; Rizvi, S.A.; Borai, A.; Daghistani, M. Comprehensive Analysis of the Chemical Composition and In Vitro Cytotoxic Mechanisms of Pallines Spinosa Flower and Leaf Essential Oils Against Breast Cancer Cells. Cell Physiol. Biochem. 2017, 42, 2043-2065. [CrossRef] [PubMed]

34. Di Martile, M.; Garzoli, S.; Ragno, R.; Del Bufalo, D. Essential Oils and Their Main Chemical Components: The Past 20 Years of Preclinical Studies in Melanoma. Cancers 2020, 12, 2650. [CrossRef] [PubMed]

35. <named-content content-type="background:white">Ren, P.; Ren, X.; Cheng, L.; Xu, L. Frankincense, pine needle and geranium essential oils suppress tumor progression through the regulation of the AMPK/mTOR pathway in breast cancer. Oncol. Rep. 2018, 39, 129-137. [CrossRef]

36. Bhakkiyalakshmi, E.; Suganya, N.; Sireesh, D.; Krishnamurthi, K.; Devi, S.S.; Rajaguru, P.; Ramkumar, K.M. Carvacrol induces mitochondria-mediated apoptosis in HL-60 promyelocytic and Jurkat T lymphoma cells. Eur. J. Pharmacol. 2016, $772,92-98$. [CrossRef] [PubMed]

37. Arunasree, K.M. Anti-proliferative effects of carvacrol on a human metastatic breast cancer cell line, MDA-MB 231. Phytomedicine 2010, 17, 581-588. [CrossRef] [PubMed]

38. Calcabrini, A.; Stringaro, A.; Toccacieli, L.; Meschini, S.; Marra, M.; Colone, M.; Salvatore, G.; Mondello, F.; Arancia, G.; Molinari, A. Terpinen-4-ol, the main component of Melaleuca alternifolia (tea tree) oil inhibits the in vitro growth of human melanoma cells. J. Investig. Dermatol. 2004, 122, 349-360. [CrossRef]

39. Grayson, D.H. Monoterpenoids. Nat. Prod. Rep. 1998, 15, 435-439. [CrossRef] 
40. Bozzuto, G.; Colone, M.; Toccacieli, L.; Stringaro, A.; Molinari, A. Tea tree oil might combat melanoma. Planta Med. 2011, 77, 54-56. [CrossRef]

41. Giordani, C.; Molinari, A.; Toccacieli, L.; Calcabrini, A.; Stringaro, A.; Chistolini, P.; Arancia, G.; Diociaiuti, M. Interaction of tea tree oil with model and cellular membranes. J. Med. Chem. 2006, 49, 4581-4588. [CrossRef] [PubMed]

42. Chaouki, W.; Leger, D.Y.; Liagre, B.; Beneytout, J.L.; Hmamouchi, M. Citral inhibits cell proliferation and induces apoptosis and cell cycle arrest in MCF-7 cells. Fundam. Clin. Pharmacol. 2009, 23, 549-556. [CrossRef]

43. Ben-Yehoshua, S.; Ofir, R. Effects of Citral against Cancer, and against Pathogens of Humans and Fruits. Acta. Hortic. 2010, 877, 1465-1471. [CrossRef]

44. Cho, S.; Lee, E.; Kim, S.; Lee, H. Essential oil of Pinus koraiensis inhibits cell proliferation and migration via inhibition of p21-activated kinase 1 pathway in HCT116 colorectal cancer cells. BMC Complement. Altern. Med. 2014, 14, 275. [CrossRef] [PubMed] 